Florida A\&M University College of Law Scholarly Commons@ FAMU Law

Faculty Books and Book Contributions

Faculty Works

1976

\title{
Goldstein v. California: Sound, Fury, and Significance
}

Robert H. Abrams

Florida A \& M University College of Law, robert.abrams@famu.edu

Follow this and additional works at: http://commons.law.famu.edu/faculty-books

Part of the Law Commons

\section{Recommended Citation}

Abrams, Robert H., "Goldstein v. California: Sound, Fury, and Significance" (1976). Faculty Books and Book Contributions. 26.

http://commons.law.famu.edu/faculty-books/26

This Book Chapter is brought to you for free and open access by the Faculty Works at Scholarly Commons @ FAMU Law. It has been accepted for inclusion in Faculty Books and Book Contributions by an authorized administrator of Scholarly Commons @ FAMU Law. For more information,

please contact linda.barrette@famu.edu. 
